\title{
The outwelling hypothesis and North Inlet, South Carolina*
}

\author{
R. Dame ${ }^{1}$, T. Chrzanowski ${ }^{2}$, K. Bildstein ${ }^{3}$, B. Kjerfve ${ }^{4}$, H. McKellar ${ }^{4}$, D. Nelson ${ }^{1}$, \\ J. Spurrier ${ }^{4}$, S. Stancyk ${ }^{4}$, H. Stevenson ${ }^{5}$, J. Vernberg ${ }^{4}$ \& R. Zingmark ${ }^{4}$ \\ ${ }^{1}$ Department of Marine Science, Coastal Carolina College, Conway, South Carolina 29526, USA \\ ${ }^{2}$ Department of Biology, University of Texas-Arlington, Arlington, Texas 76019, USA \\ ${ }^{3}$ Department of Biology, Winthrop College, Rock Hill, South Carolina 29733, USA \\ ${ }^{4}$ Belle W. Baruch Institute for Marine Biology and Coastal Research, University of South Carolina, Columbia, South Carolina \\ 29208, USA
}

${ }^{5}$ Department of Environmental Sciences and Microbiology, McNeese State University, Lake Charles, Louisiana 70609, USA

\begin{abstract}
Extensive measurements of material concentrations and water velocities at a transect across North Inlet, South Carolina (USA) allowed the estimation of net material and water fluxes. Sampling periods were distributed seasonally and according to tidal height. Statistical and hydrodynamic models were used to develop flux estimates for specific tidal cycles. There was a net discharge of water from the marsh-estuarine system to the Atlantic Ocean which is attributed to rainfall runoff and freshwater input from an adjacent estuary. All constitutents were exported seasonally and annually from the system - except total sediments, imported during fall and winter, and chlorophyll $a$ and zooplankton, imported in summer and fall. ATP, bird biomass and macrodetritus were exported throughout the year. Export of carbon, nitrogen and phosphorus from North Inlet is high compared to other systems studied to date. Large net fluxes of DOC during winter imply coupling with the uplands. The high rates of export of ammonium and orthophosphate along with detritus and microorganisms suggest major decomposition processes are taking place within the system. Export of ammonium and orthophosphate to the coastal ocean also suggest a feedback loop with phytoplankton utilizing these materials, then in turn phytoplankton are imported into the estuary where they are consumed and remineralized. Previous explanations of outwelling and tidal transport are examined and found to be individually lacking. It is proposed that any comprehensive explanation of the magnitude and direction of transport must include a physical explanation of water motion and the biological and physical mechanisms by which materials are added or removed from tidal waters. A comprehensive explanation of outwelling in North Inlet is proposed which describes this system as an ebb-dominated, bar-built estuary with good flow connection to the sea and with some freshwater input. It is also a fertile system with high productivity providing materials for export to the coastal ocean and utilization of other imported materials.
\end{abstract}

\section{INTRODUCTION}

Interaction between marsh-estuarine systems and the coastal ocean has been one of the more dynamic and controversial issues of ecological investigation (Nixon 1980) over the past 2 decades. At issue is the hypothesis that marsh-estuarine systems produce more material than can be degraded or stored within the systems, and that the excess material is being exported to the coastal ocean where it supports near coastal ocean productivity. This is the so called 'Outwelling' hypothesis (Odum 1980).

- Publication No. 639 of the Belle W. Baruch Institute for Marine Biology and Coastal Research
Historically, there have been 2 basic approaches to testing the 'Outwelling' hypothesis. One approach is indirect and involves the development of production and consumption budgets for either the marshestuarine system (Day et al. 1973, Pomeroy \& Wiegert 1981) or the near shore system (Hopkinson 1985). Imbalances found in the budgets are attributed to either export or import of material. The direct approach involves measurement of the fluxes of water and materials across a cross-section of a creek or inlet (Woodwell et al. 1977, Valiela \& Teal 1979). North Inlet represents the largest marsh-estuarine system from which direct net-flux measurements between a marshestuarine system and the coastal ocean have been obtained. This paper presents an overview and inte- 
gration of the findings of the team of investigators that measured synoptically transport of water and materials seasonally in 1979. Detailed analyses of the various components are, in most cases, reported elsewhere. This work is a summary statement on how the observations from North Inlet, South Carolina (USA), apply to the 'Outwelling' hypothesis.

\section{MATERIALS AND METHODS}

Site description. North Inlet estuary comprises ca 3200 ha of pristine tidal creeks $(20.6 \%)$, salt marsh $(73 \%)$, mudflats $(5.4 \%)$ and oyster reefs $(1 \%)$ near Georgetown, South Carolina, USA $\left(33^{\circ} 20^{\prime} \mathrm{N}\right.$, $79^{\circ} 20^{\prime} \mathrm{W}$ ). Water temperature varies from about $9^{\circ} \mathrm{C}$ in winter to $31^{\circ} \mathrm{C}$ in summer. The marsh-estuarine system has a single inlet to the ocean, North Inlet (Fig. 1), and the estuary is classified a Type $1 \mathrm{~A}$ (verti-

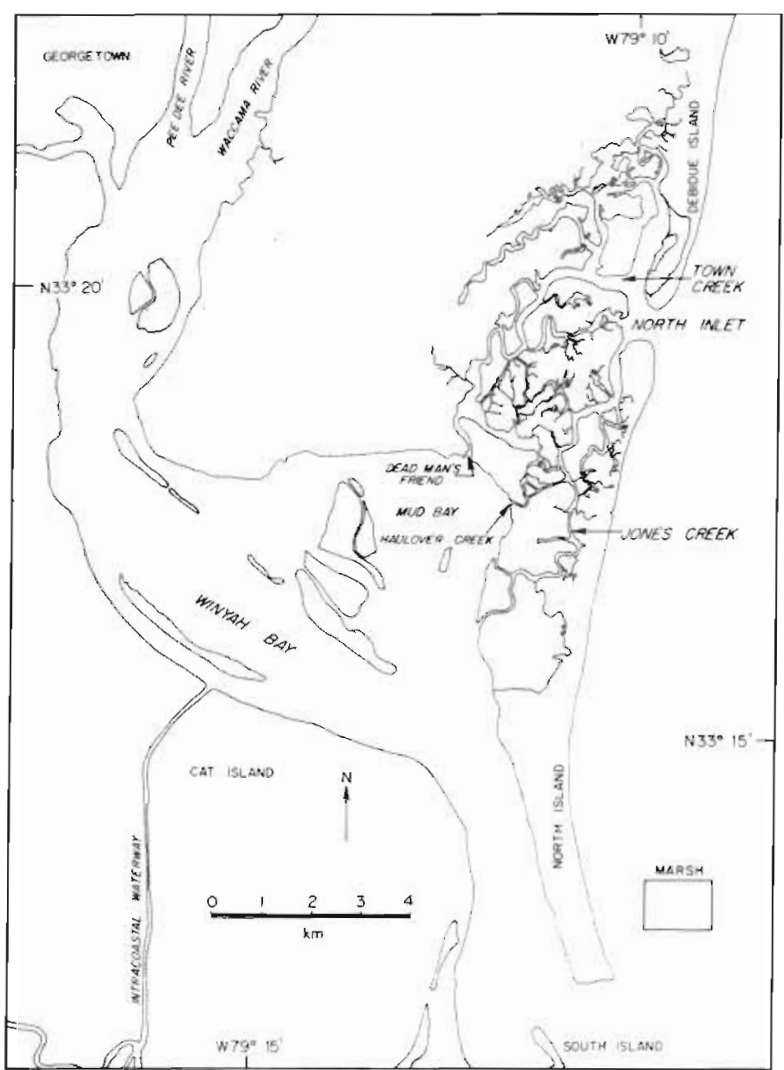

Fig. 1. Location of North Inlet, South Carolina (USA) showing Town Creek sampling transect

cally well mixed) according to the Hansen \& Rattray (1966) classification scheme. The system has 3 major tidal creeks, (Debidue, Town, Jones) which are interlaced with numerous smaller creeks. The creeks have a mean tidal range of $1.7 \mathrm{~m}$ and a mean tidal depth of $2.5 \mathrm{~m}$. Peak current velocities have been recorded at
$2.3 \mathrm{~m} \mathrm{~s}^{-1}$ in Town Creek. Northem sections of the marsh are influenced primarily by oceanic waters entering through the inlet and salinity seldom falls below $32 \mathrm{ppt}$ The ecosystem is bordered on the south by Mud Bay, a brackish water bay, thus salinities in the southern portions of the marsh are more variable. The dominant plant is the smooth cordgrass Spartina, with S. alterniflora prevalent in the northern high-salinity areas and with $S$. cynosuroides and Juncus roemaricanus more abundant in the low-salinity southern areas.

Sampling design for tidally transported materials. North Inlet has unique features that make it particularly attractive for studies on material transports. The system is large, relatively undisturbed and has discreet boundaries with limited connections to bordering aquatic environments (Fig. 1). The tidal prism of North Inlet is ca $2.1 \times 10^{7} \mathrm{~m}^{3}\left(1.2 \times 10^{7} \mathrm{~m}^{3}\right.$ to $\left.3.4 \times 10^{7} \mathrm{~m}^{3}\right)$. Water flow through Town Creek accounts for $79 \%$ of the total prism, North Jones $17 \%$, and South Jones Creek 3\% (Kjerfve et al. 1981). About $55 \%$ of the water within the system is exchanged with the sea every tidal cycle. However, considering the incomplete mixing of tidal waters throughout the entire sys tem the actual turnover time is probably considerably longer.

The major tidal creeks within North Inlet are several hundred meters wide. Tidal non-linearities (lateral stratification) cause cross-channel flows, and differences in water velocity and the concentration of dissolved and suspended materials may affect estimates of longitudinal material transports. Consequently, the number of lateral sampling stations necessary to obtain reliable estimates of longitudinal transports had to be determined. A high-density, short-term (2 tidal cycles) sampling scheme was used for this purpose. In November 1977, 10 sampling vessels were positioned across Town Creek. The boats were approximately equally spaced across the width of the creek and were moored to prevent rotational movement. Water samples for biological and chemical constituents were collected from each vessel hourly for 25 h from surface, mid, and bottom depths. Hydrographic data were obtained from surface to bottom every $30 \mathrm{~min}$ at $1 \mathrm{~m}$ depth intervals (Kjerfve et al. 1981)

The data obtained from this sampling scheme supplied the 'best' possible estimates of material transports. This intensive sampling scheme could not be maintained for extended periods fas for an annual sampling effort). Extensive statistical analysis including paired-t test, regression analysis, and percentage error comparisons led to sampling Town Creek from 9 sites (3 vessels sampling 3 depths each). Details of these analyses may be found in Kjerfve et al. (1981).

Based on the results of the transect calibration studies described above, it was determined that the 
optimal hydrography and water sample frequency needed to be once every $1.5 \mathrm{~h}$ (Kjerfve et al. 1981). Due to the variations in tidal height, 2 sets composed of 4 consecutive neap tide cycles $(50 \mathrm{~h}$ or 2 complete semidiurnal tide periods) and 4 consecutive spring tide cycles were sampled each season. This effort required ca 120 individuals sampling 3 transects twice for $50 \mathrm{~h}$ each over a 7 d period each season.

Sampling procedures for tidally transported materials. Water velocity was measured with biplane current crosses (Pritchard \& Burt 1951, Kjerfve 1975). Data were fitted by computer to a smooth curve and new velocity values were extrapolated at every $0.1 \mathrm{~m}$ depth interval from surface to bottom (Kjerfve 1975 , Kjerfve \& Proehl 1979). Water samples were pumped (Guzzler Pump, Dart Union Corp.) from 3 depths and collected in sterile, acid-washed, $500 \mathrm{ml}$ glass bottles. Samples were transported immediately on ice to laboratory facilities for chemical analyses. Ammonium was measured immediately while remaining samples were preserved.

Zooplankton were sampled with a $30 \mathrm{~cm}$ diameter $153 \mu \mathrm{m}$ mesh net with an opening mouth. The net was dropped to the bottom, opened, and hauled to the surface in a oblique tow, which relied on water currents to move water through the nets. Only 2 tidal cycles per $50 \mathrm{~h}$ period were sampled because of sample analysis time constraints. Samples were preserved in a solution of $10 \%$ formalin with rose bengal (Christy \& Stancyk 1982).

Floating macrodetritus was sampled directly by skimming material from the water surface with 2 continuously-sampling, $0.64 \mathrm{~cm}$, mesh nylon nets $6 \mathrm{~m}$ long and $0.6 \mathrm{~m}$ high. Macrodetritus was removed every $1.5 \mathrm{~h}$, bagged and returned to the laboratory where it was dried at $100^{\circ} \mathrm{C}$ and weighed (Dame 1982). Dryweight data was converted to carbon, nitrogen and phosphorus utilizing the reported values of Rice (1982).

Analytical procedures. Particulate organic carbon (POC) was measured using the method of Strickland \& Parsons (1968). POC was collected on precombusted, $47 \mathrm{~mm}$ glass-fiber filters (Whatman GF/F). The filters were held over $\mathrm{HCl}$ vapors to remove bicarbonate, placed in $10 \mathrm{ml}$ glass ampules, dried $\left(100^{\circ} \mathrm{C}\right)$, purged with oxygen, sealed and combusted for $4 \mathrm{~h}$ at $480^{\circ} \mathrm{C}$. The resulting carbon dioxide was analyzed with an infrared analyser (Beckman model 215A). Filtrate from POC samples was collected in sterile acid-washed tubes for DOC measurements. DOC was measured using the persulfate oxidation method of Strickland \& Parsons (1968).

Total nitrogen concentrations were determined by the persulfate reduction method (D'Elia et al. 1977). Utilizing a Technicon AutoAnalyzer, nitrate + nitrite concentrations were determined by the Griess reaction and ammonium concentrations by the Bethelot reaction (O'Brien \& Fiore 1962).

Total phosphorus concentrations were also analysed by the persulfate oxidation method of Menzel \& Corwin (1965). Orthophosphate concentrations were determined using the single-reagent method of Murphy \& Riley (1962).

Total suspended sediment concentrations were determined by filtering samples onto pre-weighed Whatman GF/F filters. After drying to a constant weight at $100^{\circ} \mathrm{C}$, the filters were weighed.

Total microbial biomass was estimated from adenosine triphosphate (ATP) concentrations. A boiling Tris buffer was used to extract ATP from material collected on Whatman GF/F glass fiber filters. Extractions were done in triplicate and assayed by the luciferin-luciferase technique coupled with an SAI-3000 photometer.

Chlorophyll a analyses utilized standard fluorometric techniques adapted to the freeze-thaw acetone extraction procedure (Glover \& Morris 1979). Determinations were made on a Turner-111 fluorometer.

Calculation of transport. The instantaneous transport was calculated from:

$$
F=P \sum_{j=1}^{N} \frac{h_{j}}{10}\left(0.5 V_{o j} W_{o j} C_{o j}+\sum_{j=1}^{N} V_{i j} W_{l j} C_{i j}\right)
$$

where $F=$ transport; $\mathrm{P}=$ water density; $\mathrm{h}_{\mathrm{J}}=$ depth at the $j$ th station; $V_{o j}, W_{o j}$, and $C_{0 j}=$ velocity, width, and concentration at the surface of the jth station; $V_{1 j}, W_{1 j}$, and $C_{i j}=$ velocity, width and depth at the ith depth of the $\mathrm{jth}$ station (Kjerfve et al. 1981). Single tidal-cycle transports were calculated by integrating the instantaneous mass transport values for each tidal cycle.

Sustained trends were detected, defined mathematically, and incorporated in a descriptive equation used to calculate average net transport for each 4 consecutive tidal cycles. The equation fits the behavior of all constituents except zooplankton, birds, and floating macrodetritus. The instantaneous transport for a given constituent is given by:

$$
\begin{aligned}
F=\mu & +\alpha_{1} \sin (2 \pi T / 24.84)+\beta_{1} \cos (2 \pi T / 24.84) \\
& +\alpha_{2} \sin (2 \pi T / 12.42)+\beta_{2} \cos (2 \pi T / 12.42) \\
& +\alpha_{3} \sin (2 \pi T / 6.21)+\beta_{3} \cos (2 \pi T / 6.21)+e(2)
\end{aligned}
$$

where $\mathrm{F}=$ transport; $\mathrm{T}=$ time in hours; $\mu=$ average net transport; $\alpha_{1}, \alpha_{2}, \alpha_{3}, \beta_{1}, \beta_{2}, \beta_{3}$ are regression coefficients; and e is a random error term (Chrzanowski et al. 1982). Sine and cosine terms are incorporated to explain variability resulting from tidal oscillations and reduce the standard error to permit testing for statistical significance. Estimates of the regression coefficients were made with a general linear least squares fit of the data (Chrzanowski et al. 1982, Whiting et al. 1985). 
Net seasonal flux was estimated by averaging spring-and neap-tidal flux values for each season and multiplying the average flux by the number of tidal cycles which occurred over that period. Based on the seasonal temperature cycle in North Inlet and the timing of the sampling periods, the following definitions were used: winter, $1 \mathrm{Jan}$ to $16 \mathrm{Mar}=75 \mathrm{~d}$; spring 17 Mar to $31 \mathrm{May}=76 \mathrm{~d}$; summer, 1 Jun to 30 Sep = $122 \mathrm{~d}$; fall, 1 Oct to $31 \mathrm{Dec}=92 \mathrm{~d}$.

\section{Suspended sediments}

Suspended-sediment transport indicated a net export of material on neap tides and generally an import of material on spring tides. The overall budget of sediment flux implies an export of $40 \times 10^{6} \mathrm{~kg} \mathrm{yr}^{-1}$ for the entire system or $2.2 \mathrm{~kg} \mathrm{~m}^{-2} \mathrm{yr}^{-1}$ (Table 1), similar to the results of Boon (1975) and Ward (1981).

\section{Water column: chemical components}

\section{Particulate organic carbon}

\section{RESULTS}

\section{Water flux}

The main characteristic of movement of water through North Inlet is the net lateral reversal of currents with net ebb flow dominating from the surface to bottom in the northern and deepest portion of the cross-section. On the southern and shallow portion of the cross-section, net flood-directed currents dominate. Overall ebb flux dominates flood flux. There is no gravitational vertical-longitudinal circulation (Kjerfve \& Proehl 1979). This mode of circulation is called tidal pumping and represents a non-linear interaction between tidal currents and estuarine bathymetry. Tidal pumping is intensified on spring tides.

On a seasonal and yearly basis, there is a net flux of water from North Inlet (Table 1). The discharge of water is higher per tide in winter and lower in summer. The net discharge of water may be the result of freshwater input from land runoff and from Winyah Bay which may reduce salinities at low water an average of 2 ppt particularly on spring tides (Kjerfve \& Proehl 1979).
Concentrations of POC were strongly correlated with course of a tidal cycle. Two patterns were observed: in winter, high concentrations at high tide and low concentrations at low tides; and the inverse in summer of low concentrations at high tide and high concentrations at low tide. Seasonal mean concentrations varied from 1.2 to $1.5 \mathrm{~g} \mathrm{POC} \mathrm{m}^{-3}$ (Chrzanowski et al. 1982).

Regardless of the pattern in concentration, the transport of POC was periodic with peak transports corresponding to peak discharge of water. POC was exported from Town Creek on 30 of the 32 tidal cycles (94\%), which resulted in a net outwelling of POC during each season (Table 1) (Chrzanowski et al. 1982).

\section{Dissolved organic carbon}

DOC concentrations were variable, ranging from 1.0 to $13.0 \mathrm{~g} \mathrm{C} \mathrm{m}^{-3}$. Apart from winter, DOC concentrations were uncorrelated with tidal oscillations. The net This export ranged from 5 to $480 \mathrm{~g} \mathrm{C} \mathrm{s}^{-1}$, with spring tide values being greater than neap tide values. Howtidal events. Levels of POC varied 2 to 4 -fold over the transport of DOC was always ebb directed (Table 1).

Table 1. Seasonal and yearly water discharge and carbon flux for North Inlet

\begin{tabular}{lccrrr}
\hline & Winter & Spring & Summer & Fall \\
\hline Discharge & $8.8 \times 10^{8}$ & $3.8 \times 10^{8}$ & $10.2 \times 10^{8}$ & $4.2 \times 10^{8}$ & $27.0 \times 10^{8}$ \\
Total seds & $-8.2 \times 10^{6}$ & $2.8 \times 10^{7}$ & $2.3 \times 10^{7}$ & $-2.8 \times 10^{6}$ & $4.0 \times 10^{7}$ \\
POC & $5.1 \times 10^{5}$ & $7.5 \times 10^{5}$ & $1.3 \times 10^{6}$ & $4.2 \times 10^{5}$ & $3.0 \times 10^{6}$ \\
DOC & $2.3 \times 10^{6}$ & $1.0 \times 10^{6}$ & $3.2 \times 10^{6}$ & $1.3 \times 10^{6}$ & $7.8 \times 10^{6}$ \\
TOC & $2.7 \times 10^{6}$ & $1.5 \times 10^{6}$ & $4.0 \times 10^{6}$ & $1.8 \times 10^{6}$ & $1.0 \times 10^{7}$ \\
ATP-C & $1.6 \times 10^{5}$ & $1.4 \times 10^{5}$ & $1.2 \times 10^{5}$ & $1.1 \times 10^{5}$ & $5.3 \times 10^{5}$ \\
Phytoplankton & $4.4 \times 10^{4}$ & $1.6 \times 10^{4}$ & $-5.4 \times 10^{3}$ & $-1.1 \times 10^{4}$ & $4.2 \times 10^{4}$ \\
Zooplankton & $1.1 \times 10^{4}$ & $4.7 \times 10^{4}$ & $-6.9 \times 10^{4}$ & $-1.7 \times 10^{4}$ & $-2.8 \times 10^{4}$ \\
Macrodetritus & $5.6 \times 10^{2}$ & $2.3 \times 10^{2}$ & $2.0 \times 10^{4}$ & $9.8 \times 10^{2}$ & $2.1 \times 10^{4}$ \\
Birds & - & 73 & $-1.0 \times 10^{3}$ & - & $-1.1 \times 10^{3}$ \\
Carbon in kg & Discharge in $\mathrm{m}^{3}$ & Import $=-$ & Export $=+$ (sign not shown) & & \\
\hline
\end{tabular}


ever, only $50 \%$ of the transport estimated yielded transports significantly different from zero (Chrzanowski et al. 1983).

\section{Nitrogen}

The concentrations of total nitrogen, ammonium and nitrate + nitrite were higher in summer and fall and lower in winter. Ammonium and nitrate + nitrite exhibited distinct tidal patterns especially during the fall and summer with rising concentrations on ebbing tides and falling concentrations on flooding tides. Peak ammonium concentrations ( 8 to $10 \mu \mathrm{M}$ ) occurred during fall ebb tides while lowest values $(<1 \mu \mathrm{M})$ occurred during flood or slack high tide. Peak nitrate + nitrite concentrations $(0.6$ to $0.8 \mu \mathrm{M})$ occurred during ebb tides in summer and lowest values $(<0.2 \mu \mathrm{M})$ during flood tides in summer and fall (Whiting et al. 1985).

Net flux of total nitrogen suggests export to the coastal ocean, but few of the rates were statistically significant and there were no obvious seasonal trends (Table 2). Ammonium, however, was always exported from the marsh estuarine system; most observations were significant. Ammonium export occurred on both spring and neap tides with peak rates in summer. The export of nitrate + nitrite was higher on spring tides and usually significant, but no seasonal trends were observed (Whiting et al. unpubl.).
Phosphorus

Total phosphorus (TP) concentrations showed little seasonal variation while orthophosphate $\left(\mathrm{PO}_{4}{ }^{3-}\right)$ concentrations were higher in summer and fall. Concentrations were also higher on spring tides than on neap tides. Orthophosphate concentrations exhibited distinct tidal patterns similar to those exhibited by ammonium and nitrite and nitrate with rising concentrations on ebb tides and decreasing concentrations on flood tides. The highest orthophosphate concentrations $(0.7$ to $0.8 \mu \mathrm{M})$ were observed near low tide in summer and fall.

Phosphorus was exported during all seasons (Table 3) with maximum net transport during fall. Export estimates for orthophosphate were usually statistically significant. Annual export of orthophosphate was estimated as $1.6 \mathrm{~g} \mathrm{~m}^{-2}$ (McKellar unpubl.).

\section{Water column: biological components}

Total microbial biomass

Concentrations of total microbial biomass (as ATP) varied dramatically over a tidal cycle and on a seasonal basis. ATP concentrations in winter and fall

Table 2. Seasonal and yearly fluxes of nitrogen between North Inlet and coastal area

\begin{tabular}{|lcrrrr|}
\hline & Winter & Spring & Surniner & Fall \\
\hline Ammonia & $2.7 \times 10^{4}$ & $1.2 \times 10^{4}$ & $7.5 \times 10^{4}$ & $3.6 \times 10^{4}$ & Year \\
Nitrite + nitrate & $7.0 \times 10^{3}$ & $3.3 \times 10^{3}$ & $3.8 \times 10^{3}$ & $6.8 \times 10^{3}$ & $2.1 \times 10^{4}$ \\
Total nitrogen & $3.7 \times 10^{5}$ & $2.2 \times 10^{5}$ & $1.7 \times 10^{5}$ & $2.5 \times 10^{5}$ & $1.0 \times 10^{6}$ \\
Phytoplankton & $6.6 \times 10^{3}$ & $2.3 \times 10^{3}$ & $-8.1 \times 10^{2}$ & $-1.6 \times 10^{3}$ & $6.5 \times 10^{3}$ \\
Zooplankton & $2.6 \times 10^{3}$ & $1.1 \times 10^{4}$ & $-1.6 \times 10^{4}$ & $-3.9 \times 10^{3}$ & $-6.3 \times 10^{3}$ \\
Macrodetritus & 6.0 & $2.3 \times 10$ & $2.0 \times 10^{2}$ & $1.0 \times 10$ & $2.4 \times 10^{2}$ \\
Birds & - & $1.9 \times 10$ & $2.7 \times 10^{2}$ & & $2.7 \times 10^{2}$ \\
Nitrogen in $\mathrm{kg}$ & Export $=+$ (no sign shown) & Import $=-$ & & & \\
\hline
\end{tabular}

Table 3. Seasonal and yearly flux of phosphorus between North Inlet and coastal ocean

\begin{tabular}{|lcccrr|}
\hline & Winter & Spring & Summer & Fall & Year \\
\cline { 2 - 6 } $\mathrm{TP}$ & $2.3 \times 10^{4}$ & $7.8 \times 10^{3}$ & $2.0 \times 10^{4}$ & $2.2 \times 10^{4}$ & $7.3 \times 10^{4}$ \\
$\mathrm{PO}_{4}$ & $4.2 \times 10^{3}$ & $4.9 \times 10^{3}$ & $1.2 \times 10^{4}$ & $1.8 \times 10^{4}$ & $4.0 \times 10^{4}$ \\
$\mathrm{Phytoplankton}_{\text {Zooplankton }}$ & $4.1 \times 10^{2}$ & $1.5 \times 10^{2}$ & $-5.1 \times 10$ & $-1.0 \times 10^{2}$ & $4.1 \times 10^{2}$ \\
Macrodetritus & $2.7 \times 10^{2}$ & $1.1 \times 10^{3}$ & $-1.6 \times 10^{3}$ & $-4.0 \times 10^{2}$ & $-2.5 \times 10^{2}$ \\
Birds & 1.0 & 2.0 & $2.0 \times 10$ & 1.0 & $2.4 \times 10$ \\
Phosphorus flux in kg & Export $=+$ (no sign shown) & Import $=-$ & $3.1 \times 10$ & - & $3.3 \times 10$ \\
\end{tabular}


reached minimal values during low tides and high values during high tides. In spring, ATP concentrations were out of phase with the tide; the highest values occurring at low tides. Regardless of the season, ATP levels typically varied 2 to 4 -fold over the course of a tidal cycle. Lowest seasonal levels of ATP were observed during winter and fall, and averaged 0.65 and $0.77 \mathrm{mg} \mathrm{ATP} \mathrm{m}^{-3}$ respectively, while highest concentrations of ATP were found during spring (Chrzanowski et al. 1979).

Transport of ATP was periodic with peak transports corresponding to maxima in water discharge. ATP was exported from Town Creek during $81 \%$ of the tidal cycles for which the transport was determined (Table 1). At any given time the amount of ATP moving with the tide was 1 to 2 orders of magnitude greater than the net transport per tidal cycle (Chrzanowski et al. 1979).

\section{Phytoplankton}

Concentration of chlorophyll a $(\mathrm{Chl}$ a) on a tidal cycle ranged from 1 to $35 \mathrm{mg} \mathrm{Chl} \mathrm{a} \mathrm{m} \mathrm{m}^{-3}$ with variations in winter, spring and fall usually in phase with tidal fluctuation. Peak concentrations were often biomodally distributed around high tide, with highest levels occurring just before and after high water. In summer, $\mathrm{Chl}$ a concentrations usually fluctuated out of phase with the tide, with highest concentrations occurring near low water. The magnitude of ChI a flux was significantly correlated with cell volume. Phytoplankton carbon, calculated from measurements of cell volume, varied from 2 to 10 -fold during a single tidal cycle, with concentrations correlating highly and directly with tidally induced current velocities. Phytoplankton carbon was imported in summer and fall and exported during winter and spring (Table 1).

Measurements of $\mathrm{Chl} \mathrm{a}$ and cell volumes in creekwater transferred to floating carboys in the creek did not vary significantly over time as did similar measurements taken simultaneously from the creek. This was interpreted to indicate that variations of $\mathrm{Chl} a$ and cell volumes observed in the creek were associated with tide rather than with phased physiological rhythms of phytoplankton cells. Concomitant measurements of the species composition of phytoplankton showed that although the numbers of cells in composite, velocityweighted, flood-tide samples were not significantly different from composite ebb-tide samples, the relative species compositions were distinct. Populations of the dominant species (typically centric forms), measured in flood-tide water, were reduced by about $35 \%$ in ebb-tide water and replaced by species generally considered benthic (mostly pennate forms).

\section{Zooplankton}

Concentration (numbers) of zooplankton in waters of North Inlet varied from $7.5 \times 10^{3}$ to $5.1 \times 10^{4} \mathrm{~m}^{-3}$ with highest concentrations on neap tides in summer and lowest concentrations on spring tides in winter. Dominant organisms (usually copepods) changed seasonally, with Centropages hamatus dominant in winter, Acartia tonsa and Parvocalanus crassirostris dominant during the rest of the year. Larvae, especially crab zoeae and barnacle nauplii, were abundant periodically.

Total zooplankton are exported in winter and spring and imported in summer and fall. Individual zooplankton components do not necessarily reflect overall trends, though Acartia tonsa does. Crab zoeae are found mainly in spring and summer and are always exported. Other forms and additional sampling are discussed by Christy \& Stancyk (1982) and Costello \& Stancyk (1983).

Net transport of total zooplankton mass varied from an export of $11 \mathrm{~kg}$ cycle ${ }^{-1}$ to an import of $23 \mathrm{~kg}$ cycle $^{-1}$. These dry weight values were converted to carbon, nitrogen and phosphorus using the relations determined by Parsons \& Takahashi (1973); they are given in Tables $1,2 \& 3$.

\section{Macrodetritus}

Floating macrodetritus makes up more than $90 \%$ of the total macrodetritus flux in North Inlet (Dame 1982). The flux of floating macrodetritus is highly variable and appears to be a function of season and tidal height. This material is exported throughout the year (Table 1) with a seasonal maximum in summer and fall (Dame 1982, Dame \& Stilwell 1984).

\section{Avian transport}

Censuses of the avian community inhabiting the marsh in the Town Creek drainage basin allowed an estimated density of 2.6 birds ha $^{-1}$ and a biomass of 0.7 $\mathrm{kg} \mathrm{ha}^{-1}$ dry weight; 95 species of birds were observed feeding on the marsh during the 2 yr study period. White ibises Eudocimus albus made up $33 \%$ of the biomass; clapper rails Rallus longirostris made up $30 \%$; and Charadriiformes, especially short-billed dowitchers Limnodromus griseus, made up $20 \%$.

Daily food requirements of the avian community were calculated by combining avian standing crop estimates with a bioenergetic model of metabolic energy expenditures for passerine and non-passerine birds (Wiens \& Dyer 1977). The avian community is 
estimated to have consumed $8.1 \times 10^{5} \mathrm{kcal}$ of food annually (Christy et al. 1981). Export derived from bird metabolism, including growth and excluding respiration, is estimated to be $912 \mathrm{~kg} \mathrm{C}$ for spring and 12566 $\mathrm{kg} \mathrm{C}$ for summer

\section{DISCUSSION}

\section{Water flux}

There was a consistent net discharge of water to the coastal ocean from the portion of the North Inlet basin studied. This discharge was partially due to rainfall over the marsh and surrounding maritime forest. Some of this water reached the system as surface water runoff, to a lesser degree as ground water input. Estimates of mean freshwater supply from these sources ranged from 1 to $5 \mathrm{~m}^{3} \mathrm{~s}^{-1}$ (Kjerfve \& McKellar 1980). Another input of freshwater to the system was from the adjacent Winyah Bay, which changed in elevation in response to water runoff from its extensive drainage basin. When water levels in Winyah Bay and North Inlet were high, water flowed from the bay via creeks into North Inlet. This event usually occurs in the late winter and early spring. Far-field forcing or windinduced low-frequency continental shelf waves are propagated along the eastern coast of the United States causing variations in sea level inside the estuary and in the area of marsh covered. North-east winds may cause an increase in water level of as much as $0.8 \mathrm{~m}$ in October, while summer winds from the south-west may lower estuarine sea level. The net result is an interaction between North Inlet and Winyah Bay in late winter and October; this is supported by the high discharge rates observed in late winter (Table 1).

\section{Suspended sediments}

Total suspended sediments, composed of $20 \%$ organic and $80 \%$ inorganic material, comprise the largest flux of particulate material in this study. There appears to be a seasonal trend in the flux of total sediments with import occurring in fall and winter and export in spring and summer (Table 1). Both physical and biological processes may influence the resuspension of sediments in marsh-estuarine systems (Jordan \& Valiela 1983). As water temperatures decline in fall and during winter, concentrations of suspended sediments in the water column also decline. Biological activity on or near the bottom also decreases with temperature; this implies less resuspension activities by organisms during colder periods (Ward 1981). The winter decline in suspended sediments may also be due to colder temperatures enhancing the cohesive- ness of the mucus- bound matrix on the bottom and further inhibiting resuspension by all mechanisms (Nelson unpubl.). Recent evidence from flume studies (Wolaver et al. unpubl.) shows that North Inlet marshes are sinks for inorganic sediments, but organic sediment flux is quite variable from tide to tide.

Water velocity, wind and rain have also been shown the influence the resuspension of sediments in marshestuarine systems (Ward 1981, Jordan \& Valiela 1983). But as the highest concentrations of suspended sediments were not found at maximum flood or ebb velocities, water velocity does not appear to be a major controlling influence on the suspended-sediment concentrations at the system level. Wind, however, may play a role in winter by resuspending sandy sediments in the littoral-drift zone of the coastal ocean, including the sandy beach and ebb tidal delta areas present around the entrance to North Inlet. The strongest winds, and thus the most energetic waves, are generated out of the north-east along the South Carolina coast during fall and winter.

\section{Carbon fluxes}

Particulate organic carbon was exported to the Atlantic Ocean from North Inlet on 30 of the 32 tidal cycles sampled during this study. There was an annual export of $125 \mathrm{gC} \mathrm{m}^{-2} \mathrm{yr}^{-1}$ of POC (Table 4) which is within the range of $61 \mathrm{gC} \mathrm{m}^{-2} \mathrm{yr}^{-1}$ import to $303 \mathrm{gC}$ $\mathrm{m}^{-2} \mathrm{yr}^{-1}$ export reported from 8 studies reviewed by Nixon (1980).

The amount of living microbial carbon leaving the system was estimated by a factor of 250:1 (C:ATP, see Karl 1980, pp. 764 to 766 for a complete discussion of the validity and assumptions inherent in such a conversion). In North Inlet, ca $22 \mathrm{gC} \mathrm{m}^{-2} \mathrm{yr}^{-1}$ is exported

Table 4. Yearly carbon, nitrogen, and phosphorus flux in North Inlet on an area of marsh basis

\begin{tabular}{|c|c|c|c|}
\hline & Carbon & Nitrogen & Phosphorus \\
\hline POC & 128 & & \\
\hline $\mathrm{DOC}$ & 328 & & \\
\hline $\mathrm{NH}_{4}$ & & 6.3 & \\
\hline $\mathrm{NO}_{2}+\mathrm{NO}_{3}$ & & 0.9 & \\
\hline TN & & 42.7 & \\
\hline $\mathrm{PO}_{4}$ & & & 1.7 \\
\hline $\mathrm{TP}$ & & & 3.1 \\
\hline ATP & 22 & 3.3 & 0.2 \\
\hline Chl-a & 1.8 & 0.27 & 0.016 \\
\hline Zooplankton & -1.2 & -0.26 & -0.010 \\
\hline Macrodetritus & 0.9 & 0.01 & 0.001 \\
\hline Birds & 0.05 & 0.01 & 0.001 \\
\hline
\end{tabular}


as ATP-C (Table 4). This is several orders of magnitude greater than the amount of ATP-C thought to be exported from Gotts' marsh in Maryland (Heinle \& Flemer 1976). Because phytoplankton carbon is being imported during summer and fall, the magnitude of bacterial and fungal export is even greater than indicated by the annual ATP-C flux. The large proportion of microbial export is probably indicative of decomposition processes taking place within the North Inlet system.

Phytoplankton and total zooplankton carbon exhibit similar trends with import during summer and fall and export during winter and spring (Table 1). Both phytoplankton and zooplankton are high-quality biomass particles, but the zooplankton concentrations were operating more or less independently of water movement. There were considerable flux variations depending on species or life stage (Christy \& Stancyk 1982, Costello \& Stancyk 1983). None of the zooplankton seasonal flux values and few of the individual species fluxes were significantly different from zero. Reduced intensities of sampling for zooplankton, particularly lack of replication of day and night tidal cycles, reduced our confidence that these values are as accurate as other observed components. Phytoplankton also showed differences in species composition, with water column diatoms always dominating, though benthic forms increased in relative importance on ebbing tides (Zingmark \& Satcher unpubl.). Phytoplankton are probably consumed by benthic filter feeders such as oysters, which have sizable populations in North Inlet, and by zooplankton, which feed and complete their life cycles in the system (Dame et al. 1980).

Although birds were a minor biological component of the North Inlet system, they removed quantities of material and coupled the marsh-estuarine system to other environments, where they can increase nutrients around breeding and roosting colonies (Nixon \& Oviatt 1973). In addition, birds may play a significant role in regulating the distribution and abundance of macroinvertebrate and fish populations within the marshestuarine system (Christy et al. 1981).

Dead organic matter or detritus was continually exported from North Inlet (Table 1). Macrodetritus was composed of macroalgal particles and Spartina alterniflora leaves and shoots. Most of this material was exported on the surface as floating macrodetritus with peak export in the fall when the largest percentage of the marsh was regularly covered by the tides (Dame 1982, Dame \& Stilwell 1984). Macrodetritus made up less than $1 \%$ of annual macrophyte net primary production. Bedload transport has been suggested as an important mode of detrital export (Odum et al. 1979), but less than $10 \%$ of the macrodetrital flux in North Inlet can be attributed to the water column or bottom transport (Dame unpubl.). Microdetritus was roughly estimated by subtracting ATP-C from POC to yield an estimate of $103 \mathrm{gC} \mathrm{m}^{-2} \mathrm{yr}^{-1}$. This represents over $90 \%$ of the POC export. This material was probably composed of Spartina particles, fecal matter from animals and other solids.

The annual estimate of DOC flux in North Inlet yielded an export of $328 \mathrm{gC} \mathrm{m}^{-2} \mathrm{yr}^{-1}$ (Table 4). This amount was larger than the range of 8.4 to $140 \mathrm{gC} \mathrm{m}^{-2}$ $\mathrm{yr}^{-1}$ export from 5 different marshes reviewed by Nixon (1980). Our values for DOC export exceed by more than 30\% Turner's (1978) estimate of DOC release from Spartina alterniflora leaves in a Georgia marsh. If the release from the sediments is assumed to be about $50 \mathrm{gC} \mathrm{m}^{-2} \mathrm{yr}^{-1}$ (Pomeroy et al. 1976), the total rate of release of DOC from the Georgia marsh would be about $300 \mathrm{gC} \mathrm{m}^{-2} \mathrm{yr}^{-1}$ which is similar to the observed value of $328 \mathrm{gC} \mathrm{m}^{-2} \mathrm{yr}^{-1}$ in North Inlet. However, much of the DOC produced on the marsh is thought to be rapidly respired or transformed into POC before it can be exported (Gallagher et al. 1976). In addition, DOC may be entering the marsh-estuarine system via freshwater runoff from the surrounding uplands (Wolaver et al. 1984).

The net primary production of plants within North Inlet provides additional insights into the amount of carbon available for transport (Table 5). Total net primary production for North Inlet is $1059 \mathrm{gC} \mathrm{m}^{-2} \mathrm{yr}^{-1}$ for aerial components and $1972 \mathrm{gC} \mathrm{m}^{-2} \mathrm{yr}^{-1}$ including belowground material (Dame \& Kenny 1986). North Inlet is a very fertile system when compared with other systems upon which the 'Outwelling' hypothesis has been tested.

Total carbon export from North Inlet was $453 \mathrm{gC} \mathrm{m}^{-2}$ $\mathrm{yI}^{-1}$ or about $42 \%$ of the aboveground and $25 \%$ of the total net primary production within the system. The marshes within North Inlet are not eroding, and marsh surface elevation seems to be matching the rise in sea level as in Flax Pond (Armentano \& Woodwell 1975). More recent studies utilizing flumes on the marshes of North Inlet indicate that most marsh-creek interactions occur in the creekside marsh (Wolaver et al. 1985). Creekside or tall Spartina cover only $18 \%$ of the total North Inlet area with an area averaged net primary production of $449 \mathrm{gC} \mathrm{m}^{-2} \mathrm{yr}^{-1}$ aboveground, which was very close to the amount of carbon exported. The tall Spartina zone is a very dynamic zone with high rates of export and import of organic sediments (Wolaver et al. unpubl.), thus this area may be a source of some of the POC export from the system. Some of the exported carbon, notably DOC, is probably passing through the system from the uplands to the ocean as evidenced by the winter export of DOC in this study and by Wolaver et al. (1986) from daily water sample studies in North Inlet. The majority of the material 
Table 5. Area-averaged net primary production for Great Sippewissett (GS) ${ }^{1}$. Flax Pond (FP) ${ }^{2}$, and North Inlet (NI) in $\mathrm{gC} \mathrm{m}^{-2} \mathrm{yr}^{-1}$

\begin{tabular}{|c|c|c|c|}
\hline \multirow[t]{2}{*}{ Form } & \multicolumn{3}{|c|}{ Location } \\
\hline & GS & FP & NI \\
\hline Spartina (+ belowground) & $152(904)$ & $292(400)$ & $397(1310)$ \\
\hline \multicolumn{4}{|l|}{ Macrobenthic algae } \\
\hline Microbenthic algae & - & 75 & 289 \\
\hline \multirow[t]{2}{*}{ Phytoplankton } & 24 & 50 & 318 \\
\hline & 25 & 12 & 55 \\
\hline Total & $201(1105)$ & $429(829)$ & $1059(1972)$ \\
\hline \multicolumn{4}{|c|}{ 'Valiela (1984), Valiela et al. (1978) and Van Raalte et al. (1976) } \\
\hline${ }^{2}$ Woodwell et al. (1979) & & & \\
\hline
\end{tabular}

being exported may result from decomposition processes, i.e. detritus, bacteria, fungi, and DOC, and is of lower quality than material which is retained or which is imported via the water column.

\section{Nitrogen fluxes}

Annual fluxes of nitrogen in North Inlet were exports and usually large when compared to other salt-marsh systems. Ammonium exports of $6.3 \mathrm{gN} \mathrm{m}^{-2} \mathrm{yr}^{-1}$ from North Inlet are higher than the range from an import of 0.7 to an export of $4.2 \mathrm{gN} \mathrm{m}^{-2} \mathrm{yr}^{-1}$ reported in the review by Nixon (1980). The seasonal nature of the ammonium export with a summer maximum in North Inlet suggests that metabolic acitivities of animals and decomposition processes in the system may be transforming large quantities or particulate nitrogen into dissolved reduced forms. In addition, ammonium is an energy-rich reduced form compared to nitrate + nitrite which are less energy-rich and oxidized. Ammonium is preferentially taken up by phytoplankton (McCarthy et al. 1975) and more efficiently taken up by Spartina (Morris 1980) over nitrate. Probably a large proportion of the ammonium within the system is being utilized by phytoplankton and rapidly turned over. Because ammonium fluxes are maximal during summer and fall and not during the rainy season in winter, most of the ammonium available for export probably does not come from runoff from the uplands.

In most marsh systems, nitrate + nitrite is imported (Nixon 1980) due to high rates of denitrification in the anaerobic sediments. However, in North Inlet these constituents are exported during all seasons. Significant export of nitrate + nitrite during fall, when there is little upland runoff, suggest high rates of nitrification and/or lack of utilization within the system. By knowing the total volume of water within the system, the average yearly concentration of a constituent, and the yearly flux of material to/from an adjacent system (coastal ocean), the turnover time of a constituent can be calculated. Net turnover times for ammonium and nitrate + nitrite in the North Inlet water column (Table 6) are both about $2 \mathrm{~d}$. These ammonium turnover times are similar to those of Great Sippewissett (Valiela 1984) and much shorter than in Flax Pond (Woodwell et al. 1979). The turnover time for nitrate + nitrite in North Inlet is intermediate between those in Flax Pond and Great Sippewissett. The low value for Great Sippewissett is probably the result of nitrate + nitrite

Table 6. Turnover times computed from the flux of ammonia and nitrite + nitrate for Great Sippiwissett (GS) ${ }^{1}$, Flax Pond (FP) ${ }^{2}$ and North Inlet (NI) marsh-estuarine systems

\begin{tabular}{|c|c|c|c|c|c|c|}
\hline \multirow[t]{2}{*}{ Parameter } & \multicolumn{3}{|c|}{$\mathrm{NH}_{4}$} & \multicolumn{3}{|c|}{$\mathrm{NO}_{2}+\mathrm{NO}_{3}$} \\
\hline & GS & FP & NI & GS & $\mathrm{FP}$ & NI \\
\hline Area $\left(\mathrm{m}^{2}\right)$ & $4.8 \times 10^{5}$ & $5.7 \times 10^{5}$ & $2.4 \times 10^{7}$ & & & \\
\hline Volume $\left(\mathrm{m}^{3}\right)$ & $2.2 \times 10^{5}$ & $4.3 \times 10^{5}$ & $2.1 \times 10^{7}$ & & & \\
\hline Concentration $\left(\mu \mathrm{gN} \mathrm{l}^{-1}\right)$ & 42 & 50 & 31 & 10 & 95 & 5.4 \\
\hline Flux $\left(\mathrm{g} \mathrm{m}^{-2} \mathrm{yr}^{-1}\right)$ & -4.2 & -2.1 & -6.3 & -3.9 & +1.2 & -0.9 \\
\hline Turnover time (d) & 1.7 & 6.6 & 1.9 & 0.4 & 10.7 & 1.9 \\
\hline \multicolumn{7}{|c|}{ 'Valiela (1984), Valiela \& Teal (1979), Valiela et al. (1978), and Van Raalte et al. (1976) } \\
\hline
\end{tabular}


moving through that system as a result of ground-water flow (Valiela \& Teal 1979).

Although particulate nitrogen and dissolved nitrogen were not differentiated in this study, the amount of total nitrogen exported from North Inlet $\left(42.7 \mathrm{gN} \mathrm{m}^{-2}\right.$ $\mathrm{yr}^{-1}$ ) was almost double the export of this material from Great Sippewissett (Valiela et al. 1978). Some of this material, as evidenced by the ATP and POC fluxes, is particulate material with low $\mathrm{C}: \mathrm{N}$ ratios $(5.5)$ such as bacteria (Fenchel \& Blackburn 1979). However the majority of total nitrogen is exported during winter when particulate constituents are low. Wolaver et al. (1984), utilizing daily water sample data from North Inlet, found that DON concentrations are high at this time of year and they speculated that the DON is probably a major component of upland runoff.

Our data suggest that imports of phytoplankton and zooplankton nitrogen during summer and fall from the coastal ocean are larger than, or equivalent to, the seasonal nitrate + nitrite export. Over the year, phytoplankton nitrogen export balances zooplankton nitrogen import. Thus it appears that annually, only highly structured nitrogen in the form of zooplankton biomass is imported from the ocean.

\section{Phosphorus flux}

Phosphorus was exported from North Inlet during all seasons, although phytoplankton and zooplankton phosphorus is imported in summer and fall. The magnitude of orthophosphate export was $1.7 \mathrm{gP} \mathrm{m}^{-2} \mathrm{yr}^{-1}$ and was within the range of exports found by Nixon (1980) in his review of 7 marsh systems. Turnover time of orthophosphate was much shorter in North Inlet than in Great Sippewisset or Flax Pond (Table 7). Total phosphorus export was somewhat higher in North Inlet than in the systems reviewed by Nixon (1980). Nixon (1980) in his analysis of phosphorus dynamics in marsh sediments, suggested that the exported phosphorus is

Table 7. Turnover times computed from fluxes of orthophosphorus for Great Sippewisset (GS) ${ }^{1}$, Flax Pond (FP) ${ }^{2}$ and North Inlet (NI)

\begin{tabular}{|c|c|c|c|}
\hline \multirow[t]{2}{*}{ Parameter } & \multicolumn{3}{|c|}{$\mathrm{PO}_{4}$} \\
\hline & GS & $\mathrm{FP}$ & NI \\
\hline Area $\left(\mathrm{m}^{2}\right)$ & $4.8 \times 10^{5}$ & $5.7 \times 10^{5}$ & $2.4 \times 10^{7}$ \\
\hline Volume $\left(\mathrm{m}^{3}\right)$ & $2.2 \times 10^{5}$ & $4.3 \times 10^{5}$ & $2.1 \times 10^{7}$ \\
\hline Concentration $\left(\mu \mathrm{gP} \mathrm{l}^{-1}\right)$ & 31 & 55 & 16 \\
\hline Flux $\left(\mathrm{g} \mathrm{m}^{-2} \mathrm{yr}^{-1}\right)$ & -0.6 & -1.4 & -1.7 \\
\hline Turnover time (d) & 8.7 & $10 . \overline{7}$ & 3.0 \\
\hline \multicolumn{4}{|c|}{${ }^{1}$ Valiela et al. (1978) } \\
\hline${ }^{2}$ Woodwell et al. (1979) & Woodwell & Q Whitney & 1977) \\
\hline
\end{tabular}

probably derived from the decomposition of Spartina materials in the marsh sediments. Decomposition processes are faster in summer and early fall due to higher temperatures and correspond with periods of maximal phosphorus export from North Inlet. In addition, phosphorus - unlike nitrogen and carbon - cannot be fixed from the atmosphere and new phosphorus must be entering the system from the uplands or the ocean (Wolaver et al. 1984).

\section{General considerations}

North Inlet exports carbon, nitrogen, and phosphorus at higher rates than most previously studied marshestuarine systems. When the specific components are examined in detail, some constitutents are exported and others imported seasonally, and both physical and biological processes can be identified as possible factors controlling flux magnitude. Though many living materials - such as phytoplankton, zooplankton and birds - represent relatively small net chemical fluxes, when considered from a biological perspective as food resources and high quality biomass, these fluxes are indicators of reproductive and life cycle behavior.

North Inlet is similar to other marsh-estuarine systems with some constitutents being transformed within the system and some passing through from the uplands to the sea (Valiela \& Teal 1979, Nixon 1980). Chlorophyll $a$ is imported in summer and fall, while ammonium is exported during the same time period. These fluxes suggest a feed-back loop between marshestuarine system and coastal ocean. The marshestuarine system consumes and remineralizes phytoplankton with the resulting nitrogen and phosphorus returning to the coastal ocean as ammonium and orthophosphate, which are preferred nutrients for plants. Along with these nutrients, bacteria, fungi and detritus are continually exported from the system suggesting that large quantities of organic material are being transformed within North Inlet.

\section{Explanations of transport}

A number of hypotheses have been developed to explain direction and magnitude of transport of materials in marsh-estuarine systems. Tidal velocity asymmetries have been used to explain the import of suspended particulate material to the tidal flats of the Dutch Wadden Sea (Groen 1967, Postma 1967) and the export of particulates from channels within marshes (Boon 1975). Postma (1967) working primarily in mudflat areas developed the concept than when the maximum tidal velocities on the flooding and ebbing tide 
occur near low-slack water, suspended material will be imported. Boon (1975), however, working in channels surrounded by marshes, found that when maximum flood and ebb tidal velocities were near high-slack water, particulate export resulted. Both mechanisms may take place within the same estuarine system depending on the location and surrounding geomorphology (Boon 1975). Boon further found that water temperature and seasonal changes in sea level were also possible influences on net transport of particulates within marsh-estuarine systems. Based on studies of Wachapreague Inlet, Virginia, Byrne \& Boon (1976) speculated that the tendency for bedload transport in some inlet systems may change from flooddominant when the system is geologically young or open, to ebb-dominant when the system is mature or full with marsh. Boon \& Byrne (1981) followed up their earlier studies with numerical modeling utilizing basin hypsometry or the distribution of basin surface area with respect to height to describe basin flow geometry. Their results suggest that a mature or sediment-filled basin should have a greater peak discharge and greater peak velocity during ebb (ebbdominant). This suggestion can be observed by comparing the duration of rising and falling tides, which in this case should be a longer rise time than fall time, or a positive duration difference. The opposite case is an open or immature system, which has a negative duration difference and greater peak discharge during flood tide (flood-dominant). Channel configuration is also important in determining the direction of discharge. Reduction in channel cross-sectional area can lead to a reduction in basin tidal range and thus a smaller tidal prism. Tidal duration differences tend to become strongly negative for restricted channels and thus favor a flood-dominant condition. North Inlet exhibits tidal velocity asymmetries with ebb dominance (Kjerfve \& Proehl 1979) as well as seasonal changes in sea level (Kjerfve et al. 1981), but the relative importance of each of these factors to the net transport of materials between this system and the sea is not known.

The annual transport of particulate material has also been related to the geomorphology of the specific marsh-estuarine systems by Odum et al. (1979). These authors classify marsh-estuarine systems into 3 types: Type I systems are wetlands with a narrow, shallow channel connecting them to a larger body of water. This configuration results in a basin which acts as a trap both for materials produced within the basin and entering on the flooding tide. Flax Pond (Woodwell et al. 1979) is an example of this type of system and, indeed, imports particulate materials. Type II marshestuarine systems have less constriction of tidal flow and with some possible input of freshwater. Great
Sippewissett (Valiela 1984) and North Inlet are examples of this type and usually exhibit annual exports of most particulate materials. Type III marsh-estuarine systems have open flow or little geomorphological impediment (wide mouths) to particle export. This scheme appears to differ from the tidal velocity asymmetry scheme, in that a Type III marsh-estuarine system is expected to export under the Boone scheme and import under the Odum scheme. Unfortunately, neither Odum et al. (1979) nor Boon \& Byrne (1981) offer observed observations on or examples of the Type III system. Although the preceding explanations of transport focus mainly on the transports of particulate materials, dissolved materials may be influenced by water velocities and thus velocity asymmetry. Boynton et al. (1981) have found from field studies that more dissolved materials are released from estuarine sediments as water velocity increases.

From a biological perspective, it would seem the structure of the biotic components within the different geomorphological types of marsh-estuarine systems might also influence transport. It is from this perspective that Odum (1980) proposed the 'Outwelling' hypothesis which viewed the estuary as a fertile zone supporting productivity in offshore waters. Great Sippewissett, Flax Pond and North Inlet are 3 systems where there have been extensive flux studies as well as numerous studies on the productivity and distribution of plants within each system. Because the tall Spartina (creekside) marsh acts as a filter for both particulate and dissolved constitutents (Wolaver et al. 1985), we hypothesize that systems with larger proportions of tall Spartina would have less export or possibly import of many materials. This idea is supported when the 3 systems are compared. Flax Pond, a Type I system with the highest proportion of tall Spartina, is mainly an importer, while Great Sippewissett and North Inlet, Type II systems, are mainly exporters of materials and have much lower percentages of tall grass (Table 5). All 3 systems export ammonium, which may indicate that there is more ammonium available within the systems than can be utilized. The extensive development of tall grass may also be characteristic of the age of the particular system with younger systems having more tall grass (Valiela 1984) and thus more efficiently retaining particulate materials.

\section{General explanation of transport}

Any general explanation of the magnitude and direction of transport of materials between marshestuarine systems and the coastal ocean must include 2 components: a physical explanation of water motion and the biological and physical mechanisms by which 
materials are added to or removed from tidal waters. None of the hypotheses for transport outlined above are comprehensive, although they are not mutually exclusive.

For North Inlet, a comprehensive explanation of transport describes this system as a highly productive, ebb-dominated, bar-built estuary (inlet type) with good flow connection to the coastal ocean and with some fresh-water input. Thus, on an annual basis, North Inlet exports most types of materials to the coastal ocean and imports only a few constituents. In addition, our 'Outwelling' studies suggest that North Inlet is a complex coastal landscape with flows and feedback loops connecting the forest to the sea.

Acknowledgements. The authors are grateful to the hundreds of students and faculty of the University of South Carolina at Columbia and Coastal Carolina College who assisted in sampling. The analytical and technical expertise of the straff of the Field Laboratory were invaluable. This work was supported by Grant No. DEB76-83010 from the National Science Foundation, Ecosystems Section.

\section{LITERATURE CITED}

Armentano, T. V., Woodwell, G. M. (1975). Sedimentation rates in a Long Island marsh determined by ${ }^{210} \mathrm{~Pb}$ dating. Limnol. Oceanogr. 20: 452-456

Boon, J. D. (1975). Tidal discharge asymmetry in a salt marsh drainage system. Limnol. Oceanogr. 20: 71-80

Boon, J. D., Byrne, R. J. (1981). On basin hypsometry and the morphodynamic response of coastal inlet systems. Mar. Geol. 40: 27-48

Boynton, W. R., Kemp, W. M., Osborne, C. G., Kaumeyer, K. R., Jenkins, M. C. (1981). Influence of water circulation rate on in situ measurements of benthic community respiration. Mar. Biol. 65: 185-190

Byrne, R. J., Boon, J. D. (1976). Speculative hypothesis on the evolution of barrier island-inlet-lagoon systems, 2. A case study, Wachapreague, Virginia. Geol.Soc.Am. (NE/SE) 8: 159

Christy, J, Stancyk, S. (1982). Timing of larval production and flux of invertebrate larvae in a well-mixed estuary. In: Kennedy, V. (ed.) Estuarine comparisons. Academic Press, New York, p. 489-503

Christy, R. L., Bilstein, K. L., DeCoursey, P. (1981). A preliminary analysis of energy flow in a South Carolina salt marsh: wading bird. Colonial Waterbirds 4: 96-103

Chrzanowski, T. H., Stevenson, L. H., Kjerfve, B. (1979). Adenosine 5'-triphosphate flux through North Inlet marsh system. Appl. environ. Microbiol. 37: 841-848

Chrzanowski, T. H., Stevenson, L. H., Spurrier, J. D. (1982). Transport of particulate organic carbon through the North Inlet ecosystem. Mar. Ecol. Prog. Ser. 7: 231-245

Chrzanowski, T H., Stevenson, L. H., Spurrier, J. D. (1983). Transport of dissolved organic carbon through a major creek of the North Inlet ecosystem. Mar. Ecol. Prog. Ser. 13: $167-174$

Costello, J., Stancyk, S. (1983). Tidal influence upon appendicularian abundance in North Inlet estuary, South Carolina. J. Plankton Res. 5: 263-277

Dame, R. F. (1982). The flux of floating macrodetritus in the
North Inlet estuary. Estuar. coast. Shelf Sci. 15: 337-344

Dame, R. F., Kenny, P. D. (1986). Variability of Spartina alterniflora primary production in the euhaline North Inlet estuary. Mar. Ecol. Prog. Ser. 32: 71-80

Dame, R. F., Stilwell, D. (1984). The influence of environmental factors on floating macrodetritus flux in the North Inlet ecosystem. Estuar. coast. Shelf Sci. 18: 721-726

Dame, R. F., Zingmark, R., Stevenson, L. H., Nelson, D. (1980). Filter feeder coupling between the estuarine water column and benthic subsystems. In: Kennedy, $V$ (ed.) Estuarine perspectives. Academic Press, New York, p. $521-526$

D'Elia, C. F., Steudler, P. A., Corwin, N. (1977). Determination of total nitrogen in aqueous samples using persulfate digestion. Limnol. Oceanogr. 22: 760-764

Day, J. W., Smith, W. G., Wagnet, P. R. (1973). Community structure and carbon budget of a salt marsh and shallow bay estuarine system in Louisiana. Center for Wetland Resources, Publ. No. LSU-SG-72-04, Louisiana State University, Baton Rouge

Fenchel, T., Blackburn, T. H. (1979). Bacteria and mineral cycling. Academic Press, New York

Gallagher, J. L., Pfeiffer, W. J., Pomeroy, L. R. (1976). Leaching and microbial utilization of dissolved organic matter from leaves of Spartina alterniflora. Estuar, coast. mar. Sci. 4: $467-471$

Glover, H. G., Morris, I. (1979). Photosynthetic carboxylating enzymes in marine phytoplankton. Limnol. Oceanogr. 24: $510-519$

Groen, P. (1967). On the residual transport of suspended matter by alternating tidal current. Neth. J. Sea Res. 3: 564-574

Hansen, D. V., Rattray, M. (1966). New dimensions in estuary classification. Limnol. Oceanogr. 11: 319-326

Heinle, D. R. Flemer, D. A. (1976). Flows of materials between poorly flooded tidal marshes and an estuary. Mar. Biol. 35: 359-373

Hopkinson, C. S., Jr. (1985). Shallow-water benthic and pelagic metabolism: evidence of heterotrophy in the nearshore Georgia Bight. Mar. Biol. 87: 19-32

Jordan, T E., Valiela, I. (1983). Sedimentation and resuspension in a New England salt marsh. Hydrobiologia 98: 179-184

Karl, D. M. (1980). Cellular nucleotide measurements and applications in microbial ecology. Microb. Rev. 44: 739-796

Kjerfve, B. (1975). Velocity averaging in estuaries characterized by a large tidal range to depth ratio. Estuar. coast. mar. Sci. 3: 311-323

Kjerfve, B., McKellar, H. N. (1980). Time series measurements of estuarine material fluxes. In: Kennedy, V. (ed.) Estuanne perspectives. Academic Press, New York, p. 341-358

Kjerfve, B., Proehl, J. A. (1979). Velocity variability in a crosssection of a well-mixed estuary. J. mar Res. 37. 409-418

Kjerfve, B., Stevenson, L. H., Proehl, J. A., Chrzanowski, T H (1981). Estimation of material fluxes in an estuarine cross section: a critical analysis of spatial measurement density and errors. Limnol. Oceanogr. 26: 325-335

McCarthy, J. J., Taylor, W. R., Taft, J. L. (1975). The dynamics of nitrogen and phosphorus in the open waters of the Chesapeake Bay. ACS Sym. Ser. 18: 664-681

Menzel, D. W., Corwin, N. (1965). A modified single solution method for the determination of phosphate in natural waters. Analytica chim. Acta 27: 31-36

Morris, J. T (1980). The nitrogen uptake kinetics of Spartina alterniflora in culture. Ecology 61: 1114-1121 
Murphy, J., Riley, J. P. (1962). A modified single solution method for the determination of phosphate in natural waters. Analytica chim. Acta 27:30

Nixon, S. W. (1980). Between coastal marshes and coastal waters - a review of twenty years of speculation and research on the role of salt marshes in estuarine productivity and water chemistry. In: Hamilton, P., MacDonald, K. B. (ed.) Estuarine and wetland processes. Plenum Press, New York, p. 437-525

Nixon, S. W., Oviatt, C. A. (1973). Ecology of a New England salt marsh. Ecol. Monogr. 43: 463-498

O'Brien, J., Fiore, J. (1962). Ammonia determination by automated analysis. Waste Engineering 30:252

Odum, E. P. (1980). The status of three ecosystem-level hypotheses regarding salt marsh estuaries: tidal subsidy, outwelling and detritus-based food chains. In: Kennedy, V. (ed.) Estuarine perspectives. Academic Press, New York, p. 485-495

Odum, W. E., Fisher, J. S., Pickral, J. C. (1979). Factors controlling the flux of particulate organic carbon from wetlands. In: Livingston, R. J. (ed.) Ecological processes in coastal and marine systems. Plenum Press, New York, p. $69-80$

Parsons, T. R., Takahashi, M. (1973). Biological oceanographic processes. Pergamon Press, Oxford

Pomeroy, L. R., Bancroft, K., Breed, J., Christian, R. R., Frankenberg, D., Hall, T. R., Maurer, L. G. Wiebe, W. E., Wiegert, R. G., Wetzel, R. L. (1976). Flux of organic matter through a salt marsh. In: Wiley, M. (ed.) Estuarine processes, Vol. 2. Academic Press, New York, p. 270-279

Pomeroy, L. R., Wiegert, R. G. (1981). The ecology of a salt marsh. Springer Verlag, New York

Postma, H. (1967). Sediment transport and sedimentation in the estuarine environment. In: Lauff, G. $H$. (ed.) Estuaries. AAAS, Washington, D.C., p. 158-179

Pritchard, D. W., Burt, W. V. (1951). An inexpensive and rapid technique for obtaining current profiles in estuarine waters. J. mar. Res. 108: 180-189

Rice, D. L. (1982). The detritus nitrogen problem: new observations and perspectives from organic geochemistry. Mar. Ecol. Prog. Ser. 9: 153-162

Strickland, T, D. and Parsons, T. R. (1968). A practical handbook of seawater analysis. Bull. Fish. Res. Bd Can. 167 $1-311$

Turner, R. E. (1978). Community plankton respiration in a salt marsh estuary and the importance of macrophyte leachates. Limnol. Oceanogr. 23: 442-451

Valiela, I. (1984). Nitrogen in salt marsh ecosystems. In: Carpenter, E. J., Capone, D. G. (ed.) Nitrogen in the marine environment. Academic Press, New York, p. 649-678

Valiela, I., Teal, J. M. (1979). The nitrogen budget of a salt marsh ecosystem. Nature, Lond. 280: 652-656

Valiela, I., Teal, J. M., Volkmann, S., Shafer, D., Carpenter, E. J. (1978). Nutrient and particulate fluxes in a salt marsh ecosystem: tidal exchanges and inputs by precipitation and groundwater Limnol. Oceanogr. 23: 798-812

Van Raalte, C. D., Valiela, I., Teal, J. M. (1976). Production of epibenthic salt marsh algae: light and nutrient limitation. Limnol. Oceanogr. 21: 862-872

Ward, L. G. (1981). Suspended material transport in marsh tidal channels, Kiawah Island, South Carolina. Mar. Geol. 40: $139-154$

Whiting, G. J., McKellar, H. N., Kjerfve, B., Spurrier, J. D. (1985). Sampling and computational design of nutrient flux from a southeastern U.S. salt marsh. Estuar. coast. Shelf Sci. 21: 273-286

Wiens, J. A., Dyer, M. I. (1977). Assessing the potential impact of granivorous birds in ecosystems. In: Pinowski J., Kendeigh, S. C. (ed.) Granivorous birds in ecosystems. Cambridge University Press, Cambridge, p. 205-266

Wolaver, T. G., Hutchinson, S., Marozas, M. (1986). Dissolved organic carbon and particulate organic carbon in the North Inlet estuary, South Carolina - what controls these concentrations? Estuaries 9: 31-38

Wolaver, T. G., Johnson, W., Marozas, M. (1984). Nitrogen and phosphorus concentrations within North Inlet, South Carolina - speculation as to sources and sinks. Estuar. coast. Shelf Sci. 19: 243-255

Wolaver, T. G., Whiting, G., Kjerfve, B., Spurrier, J., McKellar, H., Dame, R, Chrzanowski, T., Zingmark, R., Williams, $T$ (1985). The flume design - a methodology for evaluating material fluxes between a vegetated salt marsh and the adjacent tidal creek. J. exp. mar. Biol. Ecol. 91: 281-291

Woodwell, G. M., Houghton, R. A., Hall, C. A. S., Whitney, D. E., Moll, R. A., Juers, D. W. (1979). The Flax Pond ecosystem study: the annual metabolism and nutrient budgets of a salt marsh. In: Jefferies, R. L. (ed.) Ecological processes in coastal environments. Blackwell Scientific Pub., Oxford, p. 491-511

Woodwell, G. M., Whitney, D. E., Hall, C. A. S., Houghton, R. A. (1977). The Flax Pond ecosystem study: exchange of carbon in water between a salt marsh and Long Island Sound. Limnol. Oceanogr. 22: 823-828

Woodwell, G. M., Whitney, D. E. (1977). Flax Pond ecosystem study: exchanges of phosphorus between a salt marsh and the coastal waters of Long Island Sound. Mar. Biol. 41:1-6 